\title{
Hubungan antara Perilaku Sikat Gigi, Merokok, dan Diabetes Melitus dengan Status Karies Gigi di Indonesia: Analisis Data Riskesdas 2013
}

\author{
The Relationship Between Toothbrush Behavior, Smoking, and Diabetes \\ Mellitus With Dental and Oral Health Status in Indonesia: The Analysis \\ Data of Indonesian National Basic Health Research (Riskesdas) 2013
}

\author{
Tince Arniati Jovina ${ }^{1}$ dan Made Ayu Lely Suratri ${ }^{1}$ \\ 1) Pusat Penelitian dan Pengembangan Sumber Daya dan Pelayanan Kesehatan, Jalan Percetakan Negara No. 29 Jakarta \\ 10560, Indonesia \\ Korespondensi: t.a.jovina@gmail.com
}

Submitted: 19 Maret 2019, Revised: 25 April 2019, Accepted: 30 April 2019

https://doi.org/10.22435/jpppk.v3i1.1571

\begin{abstract}
Abstrak
Masalah status kesehatan gigi dan mulut merupakan masalah kesehatan di Indonesia yang belum mendapat prioritas tinggi. Hasil Riskesdas menunjukkan peningkatan dari 46.7\% (2007) menjadi 52.65\% (2013). Analisis terhadap faktor-faktor yang berhubungan dengan kejadian karies dapat membantu merumuskan kebijakan dan program kesehatan gigi dan mulut. Tujuan analisis ini adalah untuk mengetahui hubungan antara perilaku sikat gigi, merokok, dan diabetes dengan status karies gigi. Analisis Univariat, Bivariat dan Multivariat (regressi) data Riskesdas 2013 dengan jumlah responden 37.077 orang. Indeks DMFT digunakan untuk mengukur tingkat keparahan karies gigi. Kejadian karies gigi yang berat cenderung lebih tinggi pada responden yang pernah merokok dan yang merokok aktif dibandingkan pada mereka yang tidak pernah merokok. Responden yang sering mengkonsumsi makanan manis, mempunyai tingkat keparahan karies gigi yang lebih tinggi dibandingkan responden yang jarang atau tidak pernah mengkonsumsi makanan manis. Responden dengan kadar gula darah $>200 \mathrm{mg} / \mathrm{dl}$ mengalami kejadian karies gigi lebih tinggi. Analisis regressi logistik menunjukan variabel umur merupakan prediktor terkuat kejadian karies. Variabel lainnya yaitu jenis kelamin, pendidikan, perilaku merokok dan konsumsi makanan manis, mempunyai hubungan yang lemah terhadap kejadian karies gigi. Sedangkan variabel lainnya yaitu status kawin, tempat tinggal (desa atau kota), kadar gula darah sewaktu, pendidikan, pekerjaan, perilaku sikat gigi, status ekonomi tidak berhubungan dengan kejadian karies. Kejadian karies gigi dapat dipengaruhi oleh umur dan jenis kelamin, serta diperberat dengan perilaku sering makan makanan yang manis dan merokok. Perlu ditingkatkan perilaku hidup sehat agar masyarakat menjaga kesehatan giginya sejak dini dengan mengurangi makan makanan yang manis dan lengket, juga tidak merokok, serta rutin kontrol ke dokter gigi.
\end{abstract}

Kata kunci: Perilaku Sikat Gigi, Merokok, Diabetes Melitus, Status Karies Gigi

\begin{abstract}
Dental and oral health status is one of health problems in Indonesia that has not being prioritized. Riskesdas data shows an increase in caries prevalence from $46.7 \%$ (2007) to 52.65\% (2013). Analysis of the factors associated with caries incidence will support to develop e dental and oral health policies and programs. The objective of this analysis is to determine the relationship between toothbrush behavior, smoking, diabetes mellitus and dental caries status. Univariate, Bivariate and Multivariate Analysis was perform using 2013 Riskesdas data with 37,077 respondents. The DMFT index is used to measure the severity of dental caries. The incidence of severe dental caries tends to be higher in respondents who had smoked and who smoked actively than in those who never smoked. Respondents who frequently consume sweet foods, have a higher
\end{abstract}


dental caries severity compared to respondents who rarely or never consume sweet foods. Respondents with random blood sugar levels $>200 \mathrm{mg} / \mathrm{dl}$ have higher dental caries. Logistic regression analysis showed that age was the strongest predictor of caries incidence. Gender, education, smoking behavior and consumption of sweet foods, have a weak relationship with the incidence of dental caries. While other variables were marital status, residence (village or urban), blood sugar levels, education, employment, toothbrush behavior, and economic status are not related to caries incidence. The incidence of dental caries can be influenced by age and sex, and will be aggravated by the frequent behavior of eating sugary foods and smoking. A healthy lifestyle needs to be improved so that people maintain their teeth health early on by not consume foods that are sweet and sticky, also not smoking, and has routine control to the dentist.

\section{Keywords: Toothbrushing Behavior, Smoking, Diabetes Mellitus, Dental \& Oral Health Status}

\section{Pendahuluan}

Status kesehatan gigi dan mulut merupakan masalah kesehatan di Indonesia yang belum mendapat prioritas tinggi. Sebagian besar masyarakat belum memanfaatkan layanan kesehatan gigi dan mulut, walaupun ada keluhan. Hal ini disebabkan karena kurangnya kesadaran masyarakat akan pentingnya kesehatan gigi, ketidaktahuan, biaya yang tinggi, perilaku dokter gigi yang pasif dan cenderung hanya memberikan pelayanan kuratif.

Data dari Survei Kesehatan Rumah Tangga 2004 menunjukkan tingkat kesehatan gigi masyarakat masih rendah. Hal ini ditandai dengan tingkat prevalensi karies adalah 90,05\%. Karies atau lubang pada gigi merupakan penyakit endemik di Indonesia. Berdasarkan hasil laporan data kesakitan dari provinsi pada Profil Kesehatan Gigi dan Mulut di Indonesia pada Pelita V, penyakit gigi dan mulut termasuk dalam 10 besar penyakit terbanyak yang diderita masyarakat yaitu berkisar antara peringkat ke 2 dan ke 3 selama Pelita V. Gambar 1, berdasarkan data Riskesdas 2007 dan 2013, ada peningkatan prevalensi karies dari $46.7 \%$ di tahun 2007 menjadi $52.6 \%$ pada tahun $2013 .{ }^{1,3}$

Nicolau menyatakan bahwa karies gigi dipengaruhi oleh umur, jenis kelamin, lingkungan fisik dan sosial, pendidikan, lokasi tempat tinggal, perilaku, kunjungan ke dokter gigi, penggunaan fluoride, perilaku merokok, kehamilan, penghasilan keluarga, dan pengaruh psikososial.,

Diabetes Melitus mungkin merupakan faktor predisposisi bagi kenaikan terjadinya dan jumlah karies. Orang dengan Diabetes Melitus yang kronis dan tidak terkontrol berpengaruh pada karies gigi, karena bertambahnya karbohidrat yang dapat difermentasikan di dalam saliva penderita dan merupakan medium yang sesuai untuk pembentukan asam sehingga memudahkan terjadinya karies. Pada pasien yang terkontrol baik, pada anak maupun usia dewasa mengalami karies yang lebih sedikit dibanding dengan orang normal. ${ }^{4,6,8}$

Karies gigi dapat menimbulkan kerusakan dan kecacatan struktur gigitersebut dan kadang butuh biaya besar untuk pengobatan dan memperbaiki

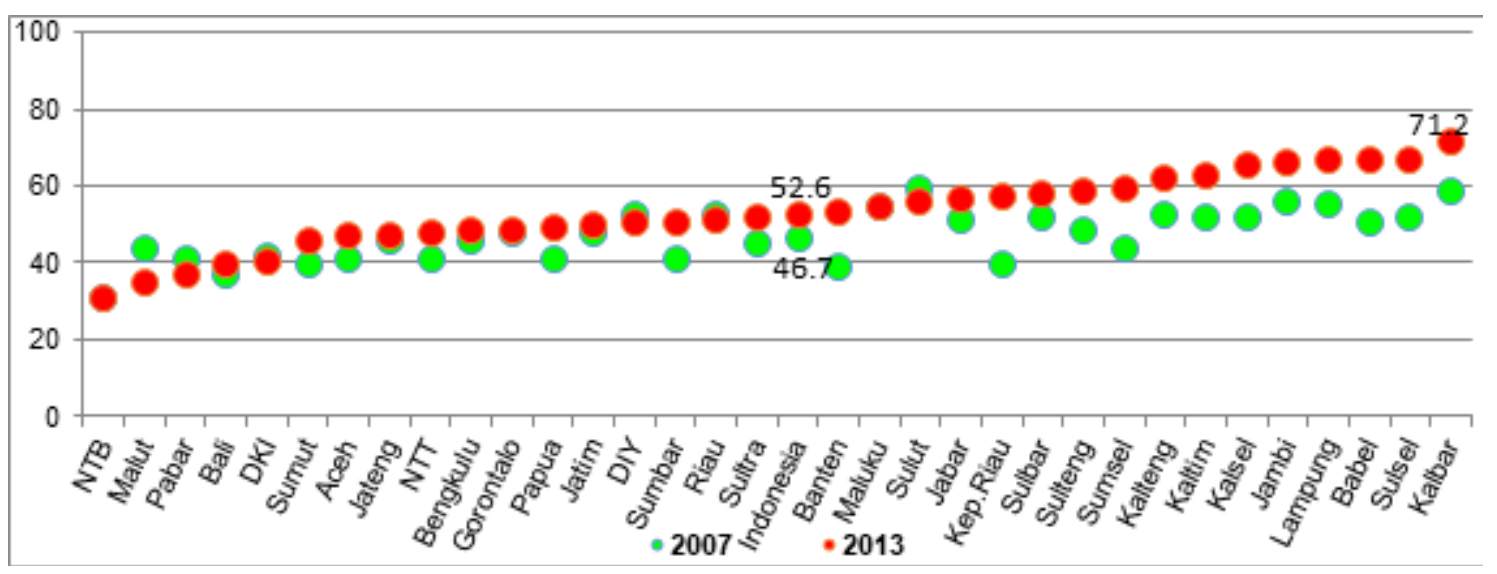

Gambar 1. Grafik prevalensi karies berdasarkan provinsi, Riskesdas 2007 dan 2013 
struktur giginya agar dapat berfungsi kembali dalam pengunyahan. Karies gigi sebenarnya dapat dicegah, bila satu atau lebih faktor penyebab karies dapat ditiadakan. Sebagai contoh bila mempunyai kebiasaan menyikat gigi untuk menghilangkan substrat karbohidrat sehingga tidak melekat pada permukaan gigi, maka karies dapat dihindari.

Analisis terhadap faktor-faktor yang berhubungan dengan kejadian karies dapat membantu merumuskan kebijakan dan program kesehatan gigi dan mulut untuk menurunkan prevalensi karies di Indonesia. Program pencegahan sangat penting dengan meningkatkan perilaku menjaga kesehatan gigi dan mulut yang baik, dalam hal ini adalah kebiasaan menyikat gigi yang tepat.

Salah satu kendala dan masih belum banyak diketahui adalah besar masalah status kesehatan gigi dan mulut berdasarkan karakteristik penduduk dan beberapa perilaku penduduk yang relevan, termasuk perilaku merokok. Selain itu potensial dipengaruhi oleh riwayat penyakit yang mendasari gangguan kesehatan secara sistemik.

Tujuan dari analisis ini adalah untuk mempelajari faktor risiko kadar gula darah sewaktu terhadap tingkat keparahan karies gigi (indeks DMF-T) dengan mempertimbangkan pengaruh variabel perilaku menjaga kebersihan mulut dalam hal ini adalah kebiasaan sikat gigi, merokok, dan konsumsi makanan manis.

\section{Metode}

Analisis ini menggunakan data Riskesdas 2013, dengan jumlah responden sebanyak 37.077 orang. Sampel studi ini adalah anggota rumah tangga (ART) dan rumah tangga (RT) dari rumah tangga terpilih di dalam BS terpilih atau BS Biomedis. Metode sampling secara bertahap dan berdasarkan sub sampel dari estimasi sampel provinsi.

Variabel-variabel studi ini yaitu :

a. Indeks DMFT untuk mengukur pengalaman seseorang terhadap karies gigi: dalam analisis univariat dan bivariat, dikelompokkan menjadi 5 kategori untuk melihat tingkat keparahannya, yaitu:
○ 0 / sangat rendah $(<1.2)$
- 1 / rendah $(1.2-2.6)$
○ 2/ sedang (2.7-4.4)

○ 3/ tinggi (4.5-6.5)

$\circ$ 4/ sangat tinggi $(>6.5)$

Hasil analisis multivariat, indeks DMF-T dibagi menjadi 2 kategori yaitu :

○ Ringan $(<1.2)$

○ Berat $(\geq 1.2)$

b. Variabel kebiasaan konsumsi makanan dibagi menjadi 3 kategori yaitu konsumsi makanan manis minimal $1 \mathrm{x}$ sehari atau lebih dikelompokan menjadi kategori sering, sedangkan konsumsi makanan manis 3-6 kali per minggu dan1-2 kali per minggu masuk dalam kategori kadang-kadang, sedangkan kebiasaan konsumsi makanan manis $<3$ kali per bulan atau tidak pernah dikategorikan menjadi jarang.

c. Status kawin :

Variabel status perkawinan dibagi menjadi 2 kategori yaitu:

- Kategori menikah/hidup bersama

- Kategori belum menikah/cerai hidup/ cerai mati/hidup berpisah

d. Variabel perilaku sikat gigi dibagi menjadi 2 kategori yaitu:

- Kategori waktu sikat gigi benar (sesudah sarapan pagi dan sebelum tidur malam)

- Kategori waktu sikat gigi diluar waktu sikat gigi yang benar.

e. Variabel perilaku merokok diklasifikasikan menjadi 3 kategori yaitu: tidak pernah merokok sama sekali, perokok aktif, kadang atau pernah merokok sebelumnya.

f. Variabel kadar gula darah sewaktu yang diukur secara kontinyu, dikelompokkan menjadi 2 kategori yaitu kategori $\geq 200 \mathrm{mg} / \mathrm{dl}$ atau $<200 \mathrm{mg} / \mathrm{dl}$.

Data dianalisis secara univariat, bivariat dan multivariat. Tahap eksplorasi data, akan dilakukan secara deskriptif dan eksploratif, baik dengan ukuran statistik deskriptif dan bentuk grafiknya pada semua variabel. Tahap analisis asosiasi sederhana akan dilakukan asosiasi antara status karies gigi dengan karakteristik responden dan variabel perilaku yang lain. Tahap analisis multivariat dilakukan dengan analisis regresi logistik dengan mengikutsertakan semua variabel yaitu variabel perilaku menjaga kebersihan mulut, penyakit Diabetes Melitus, perilaku merokok dan konsumsi makanan manis 


\section{Kerangka konsep}

Gambar 2 menunjukkan kerangka konsep yang digunakan dalam analisis data ini mengacu pada teori faktor-faktor yang berhubungan dengan kejadian karies gigi. Secara teoritis karies merupakan penyakit gigi yang multifaktorial. Empat faktor inti yang menyebabkan terjadinya karies gigi adalah host (gigi dan saliva), agent (mikroorganisme) dan lingkungan dan faktor waktu. ${ }^{11}$ Selain ke empat faktor inti yang merupakan penyebab langsung terjadinya karies gigi, terdapat faktor risiko luar yang merupakan faktor predisposisi dan faktor penghambat terjadinya karies. Faktor predisposisi tersebut antara lain usia, jenis kelamin, tingkat pendidikan, pekerjaan, tingkat sosial ekonomi, lingkungan geografis, ras dan etnis, pengetahuan dan perilaku dalam menjaga kesehatan gigi.

\section{Hasil}

Berdasarkan analisis univariat, distribusi variabelsebagaimana pada Tabel 1. Responden yang mengalami karies gigi berat (indeks DMF-T >6.6): $39 \%$, responden dengan kategori gigi sehat (indeks DMF-T $<1.2$ ): $23 \%$, responden perempuan: $62 \%$, responden terbesar pada kelompok umur 3544 tahun: $25 \%$ dan terkecil pada kelompok umur $65+$ tahun: $8 \%$, responden yang sudah menikah atau hidup bersama: $77 \%$, responden yang bertempat tinggal di pedesaan: $51 \%$, persentase terbesar berdasarkan pendidikan adalah tamatan SD: 34\% dan terkecil adalah tidak mengenyam pendidikan: $8 \%$.

Persentase responden yang bekerja adalah $55 \%$, sedangkan responden yang tidak bekerja adalah sebesar $38 \%$ dan sisanya adalah responden

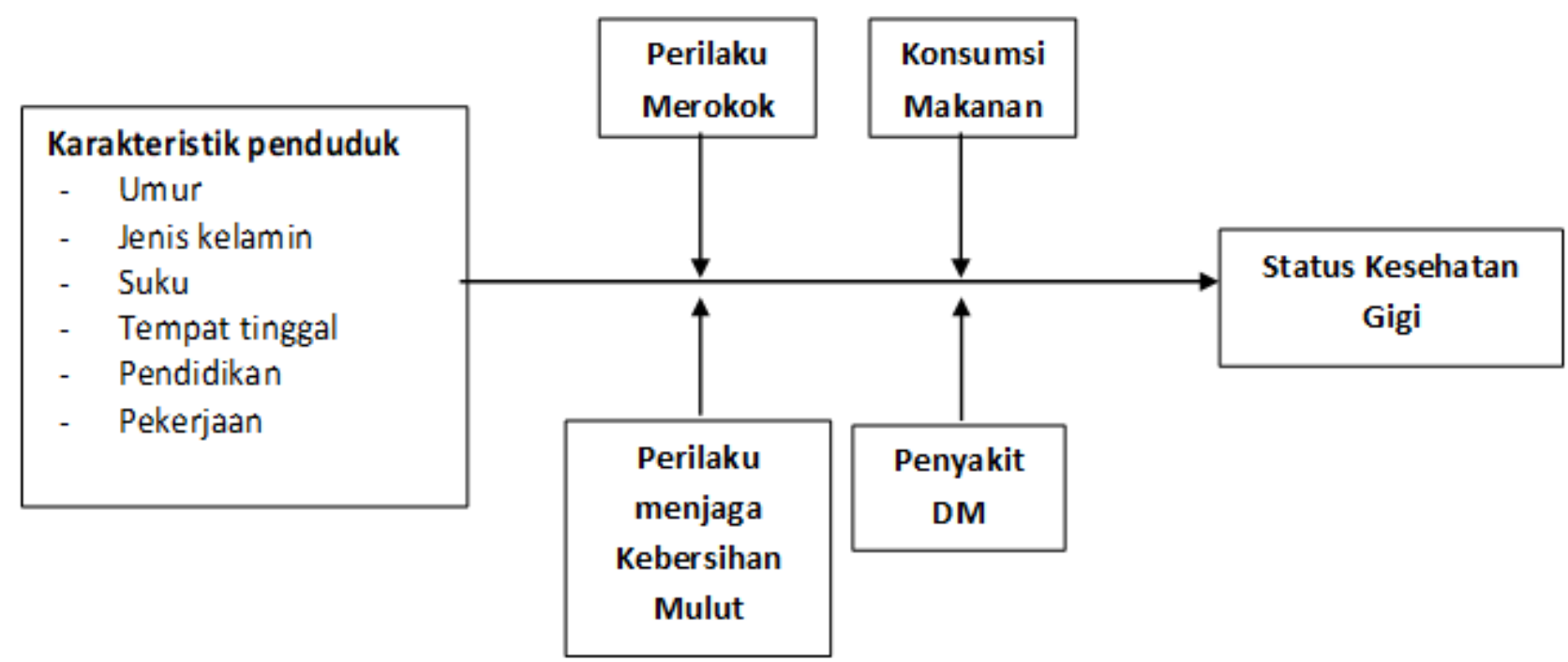

Gambar 2. Kerangka Konsep Alur Asosiasi Faktor dengan Kejadian Karies

yang sedang sekolah dan sedang mencari pekerjaan. Cukup besar persentase responden yang mengaku mempunyai kebiasaan sikat gigi tidak sesuai dengan waktu sikat gigi yang benar, yaitu sesudah sarapan dan sebelum tidur malam, sebesar 0.98 . Persentase responden yang merokok aktif sebesar $27 \%$ sedangkan responden yang tidak pernah merokok adalah 0,68 dan sisanya adalah responden yang pernah merokok (5\%). Responden yang sering mengkonsumsi makanan manis mempunyai persentase paling tinggi yaitu 53\% kemudian diikuti oleh responden yang kadang-kadang menkonsumsi makanan manis $(35 \%)$ dan responden yang jarang mengkonsumsi makanan manis (11\%). Responden yang memiliki kadar gula darah $<200 \mathrm{mg} / \mathrm{dl}$ persentasenya cukup tinggi yaitu 0,98 dibandingkan responden dengan kadar gula darah $>200 \mathrm{mg} / \mathrm{dl}$. untuk status ekonomi, distribusi persentase hampir sama antara status ekonomi menengah (23\%) dan status ekonomi menengah atas (24\%) dan paling rendah adalah status ekonomi terbawah yaitu $15 \%$.

Gambaran hubungan antara dua variabel terlihat pada Tabel 2. Pada variabel umur, terlihat semakin bertambahnya umur, maka derajat keparahan karies gigi semakin tinggi. Untuk jenis kelamin, pada perempuan, persentase yang 
Tabel 1. Persentase Status Karies Gigi dan Karakteristik Responden

\begin{tabular}{lcc}
\hline \multirow{2}{*}{ Variabel } & \multicolumn{2}{c}{$\begin{array}{c}\text { 95\% Confident } \\
\text { Interval }\end{array}$} \\
\cline { 2 - 3 } & Persentase & Lower Upper
\end{tabular}

Status Kesehatan
Gilut

Indeks DMF-T

$0(<1.2)$
$1(1.2-2.6)$
$2(2.7-4.4)$
$3(4.5-6.5)$
$4(>6.6)$

Jenis Kelamin

Laki-laki

Perempuan

Umur (tahun)

15-24

25-34

$35-44$

45-54

55-64

$65+$

\section{Status Kawin}

Kawin

Belum Kawin

Tempat Tinggal

Perdesaan

Perkotaan

Pendidikan

Tak Sekolah

Tak Tamat SD

Tamat SD

Tamat SLTP

Tamat SLTA

Tamat Diploma

Tamat PT

Pekerjaan

Tak Bekerja

Bekerja

Sedang Cari Kerja

Sekolah

Perilaku Sikat gigi

Sesuai (2x sehari)

Tidak Sesuai

\section{Perilaku Merokok}

\begin{tabular}{lrrr} 
Tidak Merokok & 68 & 67 & 69 \\
Perokok Aktif & 27 & 26 & 28 \\
Pernah Merokok & 5 & 4 & 6 \\
Konsumsi makanan & & & \\
Manis & 53 & 52 & 55 \\
Sering & 35 & 34 & 36 \\
Kadang-kadang & 11 & 10 & 12 \\
Jarang & & & \\
Kadar Gula Darah & & & \\
Sewaktu (mg/dl) & 98 & 97 & 99 \\
$<200$ & 2 & 1 & 2 \\
$\geq 200$ & & & \\
Status ekonomi & 15 & 14 & 16 \\
Terbawah & 19 & 18 & 20 \\
Menengah terbawah & 23 & 22 & 24 \\
Menengah & 24 & 23 & 25 \\
Menengah keatas & 19 & 18 & 20 \\
Teratas & & & \\
\hline
\end{tabular}

mengalami karies gigi atau indeks DMF-T $>6,5$, lebih tinggi dibandingkan laki-laki.

Responden yang tidak menikah cenderung lebih banyak mengalami karies gigi dibandingkan responden yang menikah atau yang mempunyai pasangan. Responden yang bertempat tinggal di desa mempunyai kondisi gigi yang lebih sehat (DMF-T $<1,2)$ di bandingkan responden yang tinggal di perkotaan. Responden yang tinggal di daerah perkotaan, $(0,32)$ yang mengalami karies gigi parah (DMF-T $>6,5)$

Kondisi gigi dengan indeks DMF-T $>6,5$ banyak dialami pada responden dengan tingkat pendidikan rendah yaitu tingkat sekolah dasar (baik tidak sekolah sampai tamat sekolah dasar). Responden yang mengalami karies gigi paling parah adalah pada responden yang bekerja.

Responden yang berperilaku sikat gigi yang benar diharapkan mempunyai gigi yang lebih sehat dibandingkan responden yang menyikat gigi tidak pada waktu yang tepat. Tetapi pada kenyataannya hasil kondisi gigi terbalik. Perilaku sikat gigi dapat dikatakan tidak berpengaruh terhadap tingkat karies gigi. Kejadian karies gigi yang berat (DMF-T >6.6) cenderung lebih tinggi pada responden yang pernah 
Tabel 2. Hubungan Karakteristik Responden dengan Status Kesehatan Gigi dan Mulut

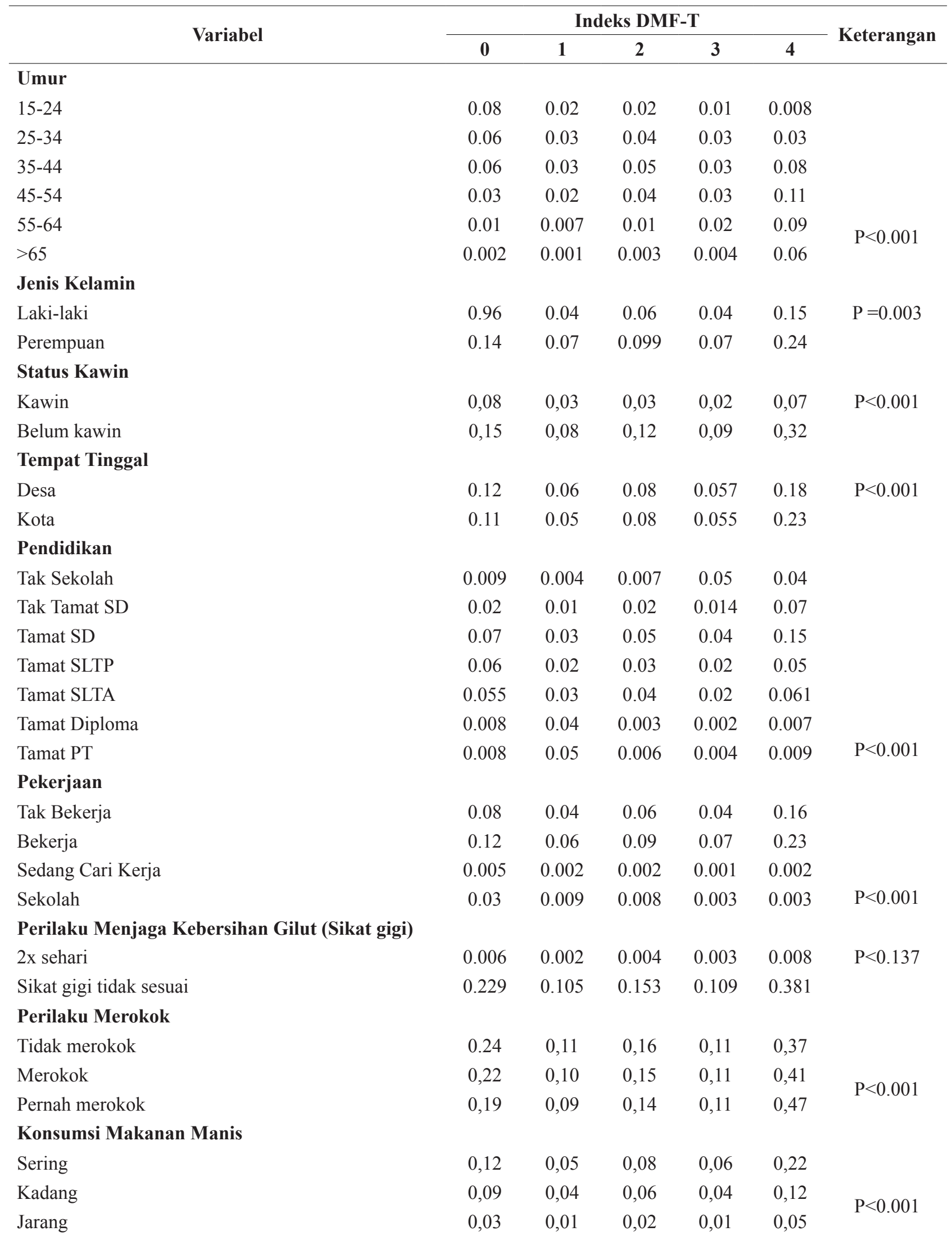




\begin{tabular}{lcccccc} 
Kadar Gula Darah & & & & & & \\
$>200$ & 0.22 & 0.10 & 0.15 & 0.12 & 0.39 & $\mathrm{P}<0.001$ \\
$<200$ & 0.003 & 0.001 & 0.003 & 0.003 & 0.01 & \\
Status Ekonomi & & & & & & \\
Terbawah & 0,24 & 0,89 & 0,14 & 0,10 & 0,4 & \\
Menengah terbawah & 0,23 & 0,09 & 0,15 & 0,10 & 0,43 & $\mathrm{P}<0,001$ \\
Menengah & 0,23 & 0,11 & 0,16 & 0,11 & 0,39 & \\
Menengah keatas & 0,25 & 0,12 & 0,16 & 0,12 & 0,35 & \\
Teratas & 0,23 & 0,13 & 0,17 & 0,12 & 0,35 & \\
\hline
\end{tabular}

merokok dan yang merokok aktif dibandingkan pada mereka yang tidak pernah merokok sama sekali.

Responden yang sering mengkonsumsi makanan manis, mempunyai tingkat keparahan karies gigi yang lebih tinggi dibandingkan responden yang jarang atau tidak pernah mengkonsumsi makanan manis. Pada responden dengan kadar gula darah diatas $\geq 200 \mathrm{mg} / \mathrm{dl}$ mempunyai kencenderungan mengalami karies gigi lebih tinggi dibandingkan responden yang mempunyai kadar gula darah $<200$ $\mathrm{mg} / \mathrm{dl}$. Responden dengan status ekonomi terbawah, kecenderungan mengalami karies gigi lebih tinggi dibandingkan dengan responden status ekonomi menengah ke atas.

Ketika semua variabel independent dimasukkan sekaligus ke dalam analisis regresi logistik, terlihat variabel umur merupakan prediktor yang sangat kuat. Terlihat semakin bertambah umur responden, odds rationya semakin meningkat. Pada Tabel 3 menunjukkan terjadi peningkatan odds ratio yang semakin besar dengan bertambahnya umur dibandingkan dengan kategori umur 15-24 tahun. Responden dengan umur 25-34 tahun, odds rationya menjadi 2x. Responden dengan umur 35-44 tahun, odds rationya 3,7. Responden kelompok umur 4554 tahun odds rationya sebesar 6,4, Responden umur 55-64 tahun odds rationya meningkat menjadi 10,4 dan pada responden usia 65 tahun keatas odd rationya menjadi 34,2 .

Variabel jenis kelamin, pendidikan, perilaku merokok dan konsumsi makanan manis mempunyai hubungan yang lemah terhadap kejadian karies gigi. Variabel lainnya yaitu status kawin, tempat tinggal (desa atau kota), kadar gula darah sewaktu, pendidikan, pekerjaan, perilaku sikat gigi, status ekonomi tidak mempunyai asosiasi.

\section{Pembahasan}

Berdasarkan hasil analisis, variabel umur dan jenis kelamin berpengaruh terhadap kejadian karies. Terlihat karies gigi meningkat tajam pada penambahan usia, artinya frekuensi pemeriksaan gigi dan mulut harus semakin sering dengan bertambahnya usia. Suwelo menyatakan bahwa dengan bertambahnya usia seseorang, karies gigi akan bertambah. Gigi yang berada lebih lama di dalam mulut akan semakin sering berinteraksi dengan faktor-faktor penyebab karies gigi. Pentingnya untuk periksa gigi secara rutin agar dapat menemukan secara dini karies gigi agar dapat mencegah karies gigi yang lebih luas sampai harus dicabut. Gejala paling dini dari karies gigi terlihat sebagai suatu bercak putih apabila plaknya telah dibersihkan. ${ }^{6}$

Hasil penelitian menunjukkan bahwa perempuan lebih berisiko mengalami karies gigi. Berdasarkan hasil penelitian terdahulu dapat disimpulkan prevalensi karies yang lebih tinggi pada perempuan karena: 1) erupsi gigi pada anak perempuan lebih awal, sehingga paparan kariogenik gigi anak perempuan dalam mulut yang lebih lama; 2) akses pasokan makanan yang lebih sering pada perempuan dengan suka mengemil sebelum waktu makan, dan 3) faktor kehamilan. ${ }^{7}$

Variabel lainnya yaitu perilaku merokok dan perilaku mengkonsumsi makanan manis ikut memberikan kontribusi pada proses terjadinya karies. Asap rokok yang terus menerus menyebabkan perubahan reseptor dari indra perasa sehingga laju aliran saliva menurun. Hal ini mempengaruhi kapasitas buffer saliva untuk menurunkan $\mathrm{pH}$ saliva, merupakan salah satu faktor penyebab meningkatnya risiko terjadinya karies gigi. ${ }^{10,11,12}$ 
Tabel 3. Hasil Analisis Multivariat Hubungan antara Perilaku Sikat Gigi, Merokok, dan Diabetes Mellitus dengan Status Kesehatan Gigi \& Mulut di Indonesia, Riskesdas 2013

\begin{tabular}{|c|c|c|c|c|}
\hline \multirow{2}{*}{ Variabel } & \multirow{2}{*}{ OR } & \multicolumn{2}{|c|}{ Confident Interval } & \multirow[t]{2}{*}{ P Value } \\
\hline & & Lower & Upper & \\
\hline \multicolumn{5}{|l|}{ Umur } \\
\hline $15-24$ & 1 & & & \\
\hline $25-34$ & 2,04 & 1,70 & 2,50 & \\
\hline $35-44$ & 3,70 & 2,90 & 4,60 & \\
\hline $45-54$ & 6,40 & 4,90 & 8,20 & $\mathrm{P}<0,001$ \\
\hline $55-64$ & 10,40 & 7,40 & 14,70 & \\
\hline $65+$ & 34,20 & 19,40 & 59,90 & \\
\hline \multicolumn{5}{|l|}{ Jenis Kelamin } \\
\hline Laki-laki & 1 & & & \\
\hline Perempuan & 1,40 & 1,20 & 1,70 & $\mathrm{P}<0,001$ \\
\hline \multicolumn{5}{|l|}{ Status Kawin } \\
\hline Tidak menikah & 1 & & & \\
\hline Kawin/Hidup bersama & 0.90 & 0,80 & 1,20 & $\mathrm{P}=0,170$ \\
\hline \multicolumn{5}{|l|}{ Tempat Tinggal } \\
\hline Desa & 1 & & & \\
\hline Kota & 1,20 & 0,80 & 1,20 & $\mathrm{P}=0,800$ \\
\hline \multicolumn{5}{|l|}{ Pendidikan } \\
\hline Tak Sekolah & 1 & & & \\
\hline Tak Tamat SD & 1,40 & 1,10 & 1,90 & $\mathrm{P}=0,020$ \\
\hline Tamat SD & 1,40 & 1,10 & 1,90 & $\mathrm{P}=0,020$ \\
\hline Tamat SLTP & 1,20 & 0,90 & 1,60 & $\mathrm{P}=0,200$ \\
\hline Tamat SLTA & 1,30 & 0,90 & 1,70 & $\mathrm{P}=0,100$ \\
\hline Tamat Diploma & 0,90 & 0,60 & 1,50 & $\mathrm{P}=0,900$ \\
\hline Tamat PT & 1,30 & 0,80 & 2,10 & $\mathrm{P}=0,200$ \\
\hline \multicolumn{5}{|l|}{ Pekerjaan } \\
\hline Tak Bekerja & 1 & & & \\
\hline Bekerja & 1,10 & 0,95 & 1,20 & $\mathrm{P}=0,200$ \\
\hline Sedang Cari Kerja & 1,01 & 0,72 & 1,40 & $\mathrm{P}=0,900$ \\
\hline Sekolah & 0,85 & 0,70 & 1,05 & $\mathrm{P}=0,100$ \\
\hline \multicolumn{5}{|c|}{ Perilaku Menjaga Kebersihan Gilut (Sikat gigi) } \\
\hline Sikat gigi tidak sesuai & 1 & & & \\
\hline $2 \mathrm{x}$ sehari & 1,10 & 0,80 & 1,50 & $\mathrm{P}=0,300$ \\
\hline \multicolumn{5}{|l|}{ Perilaku Merokok } \\
\hline Tidak merokok & 1 & & & \\
\hline Merokok & 1,30 & 1,15 & 1,60 & $\mathrm{P}<0,001$ \\
\hline Pernah merokok & 1,10 & 0,80 & 1,40 & $\mathrm{P}=0,500$ \\
\hline \multicolumn{5}{|l|}{ Konsumsi Makanan Manis } \\
\hline Sering & 1,20 & 1,10 & 1,30 & $\mathrm{P}=0,003$ \\
\hline Kadang & 1 & & & \\
\hline Jarang & 1,00 & 0,80 & 1,20 & $\mathrm{P}=0,900$ \\
\hline
\end{tabular}




\begin{tabular}{|c|c|c|c|c|}
\hline \multicolumn{5}{|c|}{ Konsumsi Makanan Manis } \\
\hline Sering & 1,20 & 1,10 & 1,30 & $\mathrm{P}=0,003$ \\
\hline Kadang & 1 & & & \\
\hline Jarang & 1,00 & 0,80 & 1,20 & $\mathrm{P}=0,900$ \\
\hline \multicolumn{5}{|l|}{ Kadar Gula Darah } \\
\hline$<200(\mathrm{~g} / \mathrm{dl})$ & 1 & & & \\
\hline$\geq 200$ & 1,10 & 0,70 & 1,70 & $\mathrm{P}=0,600$ \\
\hline \multicolumn{5}{|l|}{ Status Ekonomi } \\
\hline Terbawah & 1 & & & \\
\hline Menengah terbawah & 1,3 & 1,1 & 1,5 & $\mathrm{P}=0,010$ \\
\hline Menengah & 1,3 & 1,2 & 1,6 & $\mathrm{P}=0,001$ \\
\hline Menengah keatas & 1,3 & 1,1 & 1,6 & $\mathrm{P}=0,003$ \\
\hline Teratas & 1,4 & 0,5 & 1,6 & $\mathrm{P}=0,120$ \\
\hline
\end{tabular}

Hal ini bisa diterangkan bahwa terjadi penurunan fungsi saliva yang berperan dalam proteksi gigi, akibat merokok. Pada perokok berat menunjukkan prevalensi karies yang lebih tinggi, adanya korelasi antara karies gigi dan penggunaan tembakau. ${ }^{2,10}$ Merokok tidak hanya menimbulkan efek secara sistemik, tetapi juga dapat menyebabkan timbulnya kondisi patologis di rongga mulut. Gigi dan jaringan lunak rongga mulut, merupakan bagian yang dapat mengalami kerusakan akibat rokok. Penyakit periodontal, karies, kehilangan gigi, resesi gingiva, lesi prekanker, kanker mulut, serta kegagalan implan, adalah kasus-kasus yang dapat timbul akibat kebiasaan merokok..$^{9,11,13}$

Faktor risiko lainya adalah perilaku mengkonsumsi makanan manis, sesuai dengan teori yang mengatakan bila seseorang mengkonsumsi makanan dan minuman yang mengandung karbohidrat, maka bakteri penyebab karies di rongga mulut akan memproduksi asam sehingga terjadi demineralisasi yang berlangsung selama 2030 menit setelah makan. Diantara periode makan, saliva akan bekerja menetralisir asam dan membantu proses remineralisasi. Namun, apabila makanan dan minuman yang mengandung karbohidrat terlalu sering dikonsumsi, maka enamel gigi tidak akan mempunyai kesempatan untuk melakukan remineralisasi dengan sempurna sehingga terbentuk lubang pada gigi. ${ }^{5,12}$

Variabel pendidikan, pekerjaan, kadar gula darah sewaktu dan perilaku sikat gigi tidak terlihat berhubungan terhadap karies gigi.

\section{Kesimpulan}

Analisis data Riskesdas 2013 menunjukan determinan kejadian karies gigi adalah umur dan jenis kelamin. Karies gigi dapat di perberat bila mempunyai perilaku sering makan makanan yang manis dan merokok serta adanya penyakit sistemik seperti diabetes melitus.

\section{Saran}

Mata rantai terjadinya karies gigi ini sebenarnya dapat diputus bila seseorang mempunyai kesadaran untuk menjaga kesehatan giginya sejak dini dengan mengurangi makan makanan yang manis dan lengket, juga tidak merokok, serta rutin kontrol ke dokter gigi.

\section{Ucapan Terima Kasih}

Penulis mengucapkan terima kasih kepada Kepala Badan Litbangkes, Kesehatan RI yang telah memberikan izin untuk membuat artikel menggunakan data Riskesdas 2013. Terima kasih juga penulis ucapkan kepada Kepala Puslitbang Sumber Daya dan Pelayanan Kesehatan, Badan Litbang Kesehatan, Kementerian Kesehatan RI, serta dr. Pandu Riono, MPH, Ph.D.

\section{Daftar Rujukan}

1. Badan Litbang Kesehatan, Kemenkes RI. Pokokpokok Hasil Riset Kesehatan Dasar (Riskesdas) 2013. Jakarta, Kementerian Kesehatan RI: 2014: hal. 147-157

2. Campus G, et al. Does Smoking Increase Risk 
for Caries? A Cross-Sectional Study in an Italian Military Academy. Caries Res. 2011;45:40-46

3. Depkes RI. 2005. Badan litbang kesehatanSurvei Kesehatan Rumah Tangga (SKRT). Jakarta.

4. Diehnelt DE. Kiyak HA: Socioeconomic factors that affect Internasional caries levels.Community Dent Oral Epidemiology, Munksgaard, 2001.

5. Kebijakan Pelayanan Kedokteran Gigi Keluarga. Keputusan Menteri Kesehatan Nomel-14151 Menkes SK1X12005. Direktorat Bina pelayanan Medik Dasar, Departemen Kesehatan R1. Jakarta. 2006.

6. Kiswaluyo, Hubungan Karies Gigi Dengan Umur Dan Jenis Kelamin Siswa Sekolah Dasar Di Wilayah Kerja Puskesmas Kaliwates Dan Puskesmas Wuluhan Kabupaten Jember, Stomatognatic (J.K.G. Unej) Vol. 7 No. 12010 : 26-30

7. Lukacs, J.R. and Largaespada, L.L.:Explaining sex differences in dental caries prevalence:saliva, hormones, and "life-history" etiologies. Am. J. Hum. Biol. 18;540-555, 2006.

8. Mullally, B.H. The Influence of Tobacco Smoking on the Onset of Periodontitis in Young Persons. Tobacco Induced Diseases 2004. 2: 5365.
9. Nicolau B, Marcenes W, at al. The Life Course Approach : Explaining The Association Between Height and Dental Caries in Brazilian Adolescents. London, Community Dent and Oral Epidemiology 2005: 33; 93 - 8.

10. .Pillai HS, Jagannathan N. Tobacco - a potential threat to the oral cavity. International Journal of Pharmacy and Pharmaceutical Sciences. 2014; 6(1).p.38- 40

11. Senawa MWA, Wowor VNS, Juliatri. Penilaian resiko karies melalui pemeriksaan aliran dan kekentalan saliva pada pengguna kontrasepsi suntuk di Kelurahan Banjer Kecamatan Tikala. Jurnal e-GiGi(eG).2015;3(1):162-9

12. Upadhyaya N, Misrha R. A journey 1899 to 2013 finding associations between tobacco smoking and dental caries. Research anD Reviews: Journal of Dental Sciences (RRJDS). 2014; 2(2).p.65-70

13. Warnakulasuriya S., Dietrich T., Bornstein M., Peidró E., Preshaw P., WalterC., Wennström J., and Bergström J. Oral health risks of tobacco use and effects ofcessation. International Dental Journal 2010. 60:7-30. 